Original Paper http://ajol.info/index.php/ijbcs http://indexmedicus.afro.who.int

\title{
Anti-yeast potential of some Annonaceae species from Cameroonian biodiversity
}

\author{
TAFFOU, Jean Baptiste HZOUNDA FOKOU, Elisabeth ZEUKO'O MENKEM, \\ Lauve Rachel TCHOKOUAHA YAMTHE, Alvine NGOUTANE MFOPA, \\ Marguerite Simo KAMDEM, Vincent NGOUANA, Ide Flavie KENFACK TSAGUE and \\ Fabrice Fekam BOYOM*
}

\author{
Antimicrobial and Biocontrol Agents Unit, Faculty of Science, University of Yaoundé 1, P.O. Box 812, \\ Yaoundé, Cameroon. \\ ${ }^{*}$ Corresponding author; E-mail: fabrice.boyom@fulbrightmail.org; Tel.: +237 677276585
}

\section{ACKNOWLEDGMENTS}

The authors acknowledge the support of Seeding Labs through the Instrumental Access Grant (SL20122) to FFB.

\begin{abstract}
An increased incidence of candidiasis and cryptococcosis has been recorded within the last two decades, mainly due to the increase in number of immunocompromised patients. Moreover, the emergence of resistant pathogenic yeast strains coupled with the shortcomings of the available antifungal drugs have emphasized the need of new drugs. Within this framework, this study aimed at investigating extracts from fourteen Annonaceae plants species in vitro against the major causative agents of mycoses, namely Candida albicans, Candida parapsilosis and Cryptococcus neoformans. Plant extracts and partitioned fractions were screened by broth dilution method. Minimum inhibitory concentration (MIC) and minimum fungicidal concentration (MFC) of extracts were determined by microdilution method and subculture. Also, the effect of combined active hexane fraction (UAst $\mathrm{H}$ ) of Uvaria angolensis stem extract with the reference ketoconazole was studied. MIC values ranged from $0.625 \mathrm{mg} / \mathrm{mL}$ (for the leaf extract of Uvaria banmanni- UBl) to $\geq 10$ $\mathrm{mg} / \mathrm{mL}$. Fraction UAst $\mathrm{H}$ showed the broadest spectrum activity with MIC value of $2.5 \mathrm{mg} / \mathrm{mL}$ against all the tested yeasts. Moreover, UAst $\mathrm{H}$ exhibited synergistic interaction on $C$. albicans, $C r$. neoformans and $C$. parapsilosis when combined with ketoconazole. Overall, the results achieved in this study are promising and indicate that plants species from Annonaceae family are possible sources of potent and synergistic anti-yeast extracts.
\end{abstract}

(C) 2017 International Formulae Group. All rights reserved.

Keywords: Annonaceae, Extract, Antifungal, Combination, Synergism. 


\section{INTRODUCTION}

The HIV pandemic has greatly increased the incidence of fungal infections over the last two decades (Khan et al., 2012; Okonkwo et al., 2013). As the most implicated, Candida species are responsible for a variety of infections from superficial to systemic (Nucci and Marr, 2005; Romeo et al., 2013). Candida albicans is the most frequently isolated (Ruhnke, 2006), and is responsible for over $50 \%$ of candidemias (Hachem et al., 2008), followed by $C$. parapsilosis $(10 \%-20 \%)$, C. glabrata $(20 \%$ $30 \%)$, C. tropicalis $(17.3 \%)$ and C. krusei (1\%-5 \%) (Horn et al., 2009). In addition, HIV infection has been associated with more than $80 \%$ of cryptococcosis cases worldwide (Mirza et al. 2003; Perfect et al., 2010) with $100 \%$ mortality rate (Corbett et al., 2002) when untreated. The treatment of candidiosis and cryptococcosis is limited to drugs from few classes such as polyenes (amphotericin B, AMB), pyrimidine analogues (fluorocytosine), azoles and 1,3-betaglucan synthase inhibitors (echinocandins). However, the development of resistant pathogens along with high toxicity of these drugs have significantly impaired the control of fungal infections worldwide, stimulating the search for new, safe and more efficient drug candidates.

Plant-derived products for drugs discovery program have gained attention of scientific community since decades. In fact, medicinal plants have been the sources of variety of biologically active compounds for centuries and are used extensively as crude materials or as pure compounds for treating various conditions (Dias et al., 2012). Within this context, Cameroonian medicinal plants have been investigated against a wide range of microorganisms (Fokou et al., 2014; Sidjui et al., 2014; Kammalac et al., 2015; Kamdem et al 2015; Menkem et al., 2015; Menkem et al., 2016). However, Annonaceae species although widely investigated for their antiprotozoal activities, have gained less interest as potential sources of antifungal drugs. To fill this gap in, this study was designed to assess the anti-yeast activity of extracts from Annona muricata, Anonidium mannii, Monodora myristica, Polyalthia oliveri, Polyalthia suaveolens, Uvaria angolensis, Uvaria banmanni, Uvaria muricata, Uvariastrum zenkeri, Uvariodendron calophyllum, Uvariodendron molundense, Xylopia aethiopica, Xylopia parviflora and Xylopia africana, using Candida albicans, Candida parasilosis and Cryptococcus neoformans isolates as targets.

\section{MATERIALS AND METHODS}

\section{Plant collection}

Plant materials from Annonaceae family were harvested and identified as Annona muricata Linn, Anonidium mannii Gaertm (D. Oliver) Engl. \& Diels, Monodora myristica (Gaertn.) Dunal, Polyalthia oliveri Engl., Polyalthia suaveolens Engl. \& Diels, Uvaria angolensis Engl. \& Diels, Uvaria muricata Engl. \& Diels, Uvaria banmanni Engl. \& Diels, Uvariastrum zenkeri Engl. \& Diels, Uvariodendron calophyllum R.E Fries, Uvariodendron molundense (Engl. \& Diels), Xylopia aethiopica (Dunal) A Rich, Xylopia africana (Benth) Oliv, Xylopia parviflora A Rich. Voucher specimens were deposited at the National Herbarium of Cameroon, Yaoundé under specific reference numbers. Plants reference numbers, traditional uses, collection site, previous scientific studies and parts used are summarized in Table 1.

\section{Yeasts isolates}

Yeast isolates were provided by the Laboratory of Clinical Biology of the Yaoundé Central Hospital (Yaoundé, Cameroon), and consisted of clinical isolates of C. albicans, C. parapsilosis and $\mathrm{Cr}$. neoformans. These yeasts were maintained at room temperature $\left(25-27{ }^{\circ} \mathrm{C}\right)$ and cultured at 
$37^{\circ} \mathrm{C}$ for $24 \mathrm{~h}$ on Sabouraud Dextrose Agar (Oxoid) slants prior to use.

\section{Extracts/fractions preparation and preliminary anti-yeast screening}

One hundred grams of powder from each plant part were macerated in $1500 \mathrm{~mL}$ of ethanol (Merck) for $72 \mathrm{~h}$ at room temperature $\left(25-27{ }^{\circ} \mathrm{C}\right)$. Filtrates obtained using filter papers (Whatman no.1) were evaporated to dryness using a rotary evaporator at $80{ }^{\circ} \mathrm{C}$ (Büchi 011, Flawil Switzerland). Stock solution for each extract was prepared at $100 \mathrm{mg} / \mathrm{mL}$ using $10 \%$ DMSO. As positive control, ketoconazole (Janssen-cilag) was prepared at $200 \mathrm{mg} / \mathrm{mL}$ in sterile distilled water. Each solution was sterilized by filtration through $0.22 \mu \mathrm{m}$ sterile filter (Acrodisc Syringe Filter).

All extracts were screened by broth dilution method (CLSI, 2008) at $10 \mathrm{mg} / \mathrm{mL}$ in 96-well microtiter plates. To achieve this, 10 $\mu \mathrm{L}$ of each stock solution of extract were added in triplicate wells followed by $90 \mu \mathrm{L}$ of yeast inoculum prepared at $2.5 \times 10^{3} \mathrm{CFU} / \mathrm{mL}$ in sabouraud dextrose broth (Difco) medium. Wells containing $10 \%$ DMSO without extracts were used as negative control while ketoconazole was tested as positive control. Plates were incubated at $37{ }^{\circ} \mathrm{C}$ for $48 \mathrm{~h}$ and extracts showing $100 \%$ inhibition of fungal growth against the three tested yeasts ascertained by macroscopic observation were selected and progressed.

Fifteen grams of each selected extract were added to $150 \mathrm{~mL}$ of water and further fractionated by liquid-liquid partition between water and hexane $(v / v)$ to yield hexane and aqueous fractions. Hexane fractions were dried using rotavapor while aqueous fractions were freeze dried to obtained powders. In some few cases, interface precipitates were obtained and also tested for biological activity. Stock solution for each fraction was prepared at $100 \mathrm{mg} / \mathrm{mL}$ using $10 \%$ DMSO.
Determination of Minimal Inhibitory Concentration (MIC) and Minimum Fungicidal Concentration (MFC)

MIC values for the selected extracts and fractions were determined according to the CLSI M27-A3 protocol (CLSI, 2008) with little modifications. Briefly, a serial two-fold dilution of each extract using sabouraud dextrose broth medium (Difco) supplemented with $2 \%$ glucose was done in 96-wells microtiter plates starting with $10 \mathrm{mg} / \mathrm{mL}$ down to $0.04 \mathrm{mg} / \mathrm{mL}$. One hundred microliters of fungal inocula at the final concentrations of $2.5 \times 10^{3} \mathrm{CFU} / \mathrm{mL}$ were then added into each well of the plate to achieve a final volume of $200 \mu \mathrm{L}$. Plates were incubated at $37{ }^{\circ} \mathrm{C}$ for $48 \mathrm{~h}$. Ketoconazole was tested as positive control at three concentrations $(10,5$, and $2.5 \mathrm{mg} / \mathrm{mL})$. MIC values were determined as the lowest extract concentration exerting complete visible inhibition of the yeasts based on turbidity in plate wells through macroscopic observation. MFC values were determined by transferring $50 \mu \mathrm{L}$ aliquots of the clear wells (MIC wells) into $150 \mu \mathrm{L}$ of freshly prepared broth medium and incubated at $37^{\circ} \mathrm{C}$ for 48 hours. The MFC was defined as the lowest concentration of test sample which did not produce turbidity, indicating no microbial growth. All tests were performed in triplicates. The MIC cutoff value for fraction progression was $\leq 2.5 \mathrm{mg} / \mathrm{mL}$ against all the tested yeasts.

\section{Phytochemical screening of the selected fraction}

The most active fraction was subjected to phytochemical screening to detect the presence of secondary metabolites with potential antifungal activity, namely saponins, tannins, flavonoids, phenols, alkaloids, triterpenes, anthocyanins, essential oils and steroids as described by (Odebeyi and Sofowora, 1978). 
Table 1: Ethnobotanical and scientific information on the investigated plants.

\begin{tabular}{|c|c|c|c|c|c|}
\hline $\begin{array}{l}\text { Plants and } \\
\text { reference numbers }\end{array}$ & $\begin{array}{c}\text { Local/comm } \\
\text { on name }\end{array}$ & $\begin{array}{l}\text { Collection } \\
\text { site }\end{array}$ & Traditional indications & Scientific findings & Organs used \\
\hline $\begin{array}{l}\text { Annona muricata } \\
\text { 32879/HNC }\end{array}$ & $\begin{array}{l}\text { Graviola or } \\
\text { soursop, }\end{array}$ & Yaoundé & $\begin{array}{l}\text { Malaria, sedative, digestive, antipyretic, } \\
\text { Boil, cough, diarrhea, dermatosis, } \\
\text { hypertension, rheumatism and styptic, } \\
\text { worms and parasites. } \\
\text { headache, fever, toothache, asthma }\end{array}$ & $\begin{array}{l}\text { anthelmintic, antiplasmodial, antiparasitic, } \\
\text { antimicrobial, antipyretic, sedative, } \\
\text { antispasmodic, } \\
\text { hypotensive, anticonvulsant, digestive, } \\
\text { antitumor and anticancer (Tchokouaha et } \\
\text { al., 2015; Pinto et al., 2005) }\end{array}$ & $\begin{array}{l}\text { Leaves, twigs, flower, } \\
\text { pericarp, pulp of fruit, } \\
\text { seeds }\end{array}$ \\
\hline $\begin{array}{l}\text { Anonidium mannii } \\
\text { Gaertm } 45582 \mathrm{HNC}\end{array}$ & l & Mount Kalla & $\begin{array}{l}\text { Male infertility, complication of } \\
\text { pregnancy and childbirth, } \\
\text { treatment of abscess }\end{array}$ & $\begin{array}{l}\text { Antimycobacterial } \\
\text { (Donfack et al., 2014) }\end{array}$ & Leaves, twigs \\
\hline $\begin{array}{l}\text { Monodora miristica } \\
\text { 1927/SRFK }\end{array}$ & $\begin{array}{l}\text { Medjeng, } \\
\text { pébé, ding, } \\
\text { ikoma, ozek }\end{array}$ & Yaoundé & $\begin{array}{l}\text { Witchcraft, stimulant, stomachic, } \\
\text { headaches, sores, stomach-aches, febrile, } \\
\text { pains, eye diseases and haemorrhoids }\end{array}$ & $\begin{array}{l}\text { Antimalarial (16), Cytotoxic (Bakarnga- } \\
\text { Via et al., 2014), Antibacterial and } \\
\text { antifungal activities (Tatsadjieu et al., } \\
\text { 2003) }\end{array}$ & Leaves, twigs, stem bark \\
\hline $\begin{array}{l}\text { Polyalthia oliveri } \\
\text { 19416SRF/Cam }\end{array}$ & l & Mount Kalla & Malaria & $\begin{array}{l}\text { Antiplasmodial (Boyom et al., } \\
\text { 2009) }\end{array}$ & Leaves, twigs, stem bark \\
\hline $\begin{array}{l}\text { Polyalthia } \\
\text { suaveolens } \\
\text { 1227/SRF/CAM }\end{array}$ & Afoumengen & Mount Kalla & Dysmenorrhea & $\begin{array}{l}\text { Antimalarial activity (Cushnie and Lamb, } \\
\text { 2005] }\end{array}$ & Leaves, twigs, stem bark \\
\hline $\begin{array}{l}\text { Uvaria angolensis } \\
\text { 16797/SRF/CAM }\end{array}$ & / & Mount Kalla & Abdominal pains, dysentery, digestive & $\begin{array}{l}\text { Antiplasmodial, antimicrobial (Hufford et } \\
\text { al., 1987) }\end{array}$ & Leaves, twigs, stem \\
\hline $\begin{array}{l}\text { Uvaria banmanni } \\
6427 / \mathrm{SRF} / \mathrm{Cam}\end{array}$ & / & Mount Kalla & Fatigue, abscess & Antimycobacterial (Donfack et al., 2014) & Leaves, twigs \\
\hline $\begin{array}{l}\text { Uvaria muricata } \\
\text { HNC }\end{array}$ & / & Mount Kalla & Abdominal pains, dysentery, digestive & & Leaves, twigs, stem \\
\hline
\end{tabular}


TAFFOU et al. / Int. J. Biol. Chem. Sci. 11(1): 15-31, 2017

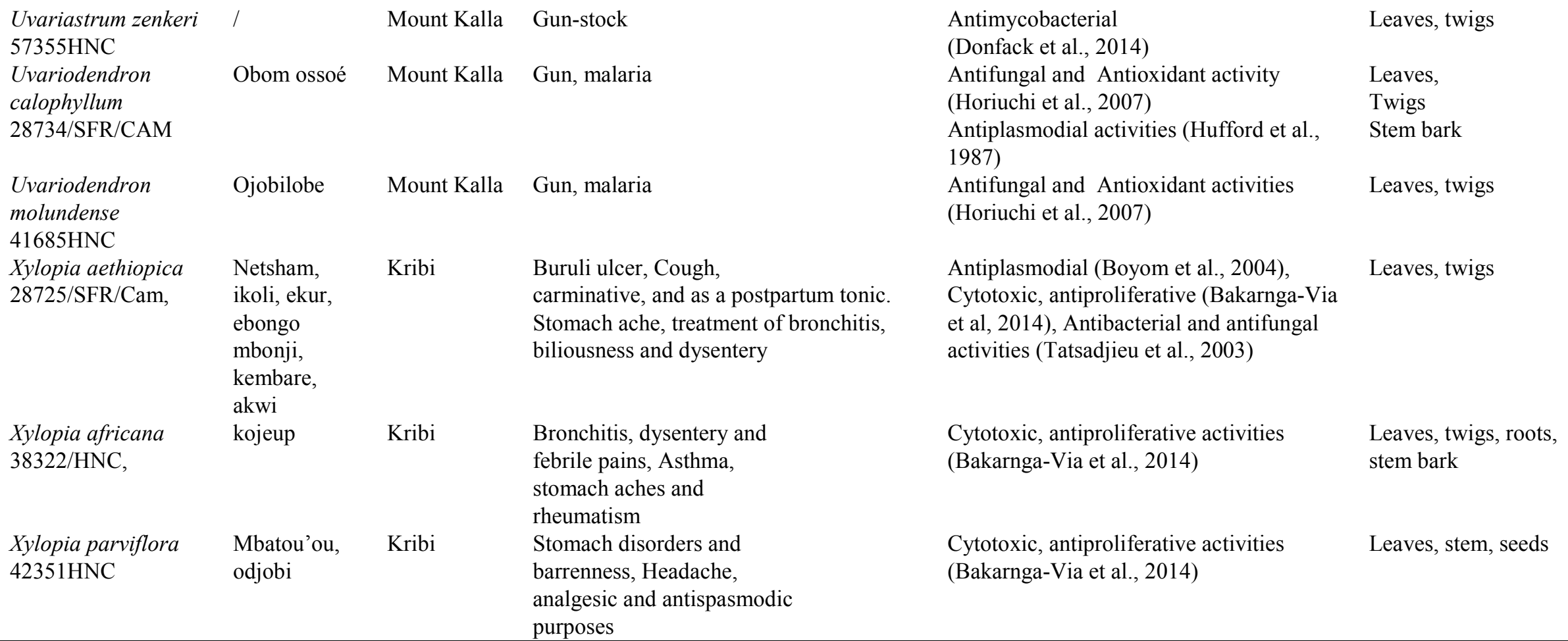

Plant samples were identified and voucher specimens deposited at the National Herbarium of Cameroon, Yaoundé. 


\section{Study of combinations of the promising fraction with ketoconazole}

The antifungal effect of combined fraction with ketoconazole was assessed by broth microdilution checkerboard technique. Checkerboard tests were used to determine fractional inhibitory concentration indexes (FICIs) of combinations against each test microorganism. The checkerboard broth microdilution method based on CLSI recommendations (CLSI, 2008) consisted of diluting the fraction and drug in the two directions of a 96-wells microplate. Mixed concentrations in wells ranged from $1 / 8 \times$ MIC to $8 \times$ MIC and $1 / 128 \times$ MIC to $8 \times$ MIC for the fraction and drug respectively. The fungal inoculum was added to give an ultimate concentration of $2.5 \times 10^{3} \mathrm{CFU} / \mathrm{mL}$ in a final volume of $100 \mu \mathrm{L}$. Plates were therefore incubated at $37^{\circ} \mathrm{C}$ for $48 \mathrm{~h}$ and each test performed in duplicate. Changes in the Fractional Inhibitory Concentration Indexes (FICIs) were calculated using the following formula, and the type of interaction was determined according to previously described criteria.

$\mathrm{FICI}(\mathrm{X} 1 / \mathrm{X} 2)=(\mathrm{MICX} 1$ in combination/MICX1 alone) + (MICX2 in combination/MICX2 alone) (Tobudic et al., 2010). According to the adopted criteria, a combination was considered synergistic when the FICI was $\leq 0.5$, additive when it was $>0.5$ to $\leq 1$, indifferent when it was $>$ 1.0 to $\leq 4.0$, and antagonistic when the obtained FICI was $>4.0$.

\section{RESULTS}

\section{Yields of plant extraction and anti-yeast} potential of fourteen Annonaceae plants

Plant samples were extracted by maceration using ethanol, and the yield of extraction calculated relative to the weight of the starting plant material. Extracts were screened for activity against yeasts. The data collected are summarized in Table 2.

The plants extraction yields varied from 0.10 to $13.94 \%$ and were highly dependent on the plants species and parts used. The preliminary antifungal screening also showed varying susceptibility of the tested yeasts. Amongst the 44 extracts prepared from 14 plants, only 13 (29.54\%) inhibited the growth of all the tested yeasts, namely $C$. albicans, $C$. parapsilosis and $C r$. neoformans at $10 \mathrm{mg} / \mathrm{ml}$, including AMfr, MMl, POl, POtw, POsb, PSl, UBl, UAl, UAtw, UAst, UMutw, UMust, and XPs. These promising extracts derived from different types of plant organ, including fruit, leaf, twig, stem, stem bark, and seed. They were selected and subjected to liquid-liquid partition coupled with MIC/MFC determination.

\section{Determination of Anti-yeast activity parameters of promising extracts and their fractions}

Table 3 below summarizes the activity parameters (MIC and MFC) of 29 fractions derived from the 13 selected crude extracts against three pathogenic yeasts, namely $C$. albicans, C. parapsilosis, and $C r$. neoformans.

The activities displayed spanned from $0.625 \mathrm{mg} / \mathrm{mL}$ to $>10 \mathrm{mg} / \mathrm{mL}$ depending on the plant extracts and yeast species. The highest potency was exhibited by the crude leaf extract of Uvaria banmanni (UBl) against $C$. albicans with an MIC value of $0.625 \mathrm{mg} / \mathrm{mL}$ and MFC of $1.25 \mathrm{mg} / \mathrm{mL}$. Besides, UBl only showed moderate effect against C. parapsilosis and Cr. neoformans with MIC of $10 \mathrm{mg} / \mathrm{mL}$ and MFC > 10 $\mathrm{mg} / \mathrm{mL}$. The other few active crude extracts inhibited the yeasts with MIC values ranging from $2.5 \mathrm{mg} / \mathrm{mL}$ to $>10 \mathrm{mg} / \mathrm{mL}$, and MFC from $5 \mathrm{mg} / \mathrm{mL}$ to $>10 \mathrm{mg} / \mathrm{mL}$. Amongst 
those, the more promising were MMl from the leaf of M. myristica, UAtw and UMutw from the twig of $U$. angolensis and $U$. muricata respectively and that showed MIC values of $5 \mathrm{mg} / \mathrm{mL}$ against the three yeasts. Extract $\mathrm{POl}$ from $P$. oliveri significantly inhibited Cr. neoformans with an MIC of 2.5 $\mathrm{mg} / \mathrm{mL}$ and MFC of $5 \mathrm{mg} / \mathrm{mL}$, but only showed moderate action against $C$. albicans and . parapsilosis (MIC $=10 \mathrm{mg} / \mathrm{mL}$ ).

As shown in Table 3, water/hexane partition of the 13 extracts (AMfr, MMl, POl, POtw, POsb, PSl, UBl, UAl, UAtw, UAst, UMtw, UMst, and XPs) yielded 29 fractions that were equally tested for biological activity, including 3 interface precipitates, MM1 I, PO1 I, and UB1 I respectively from $M$. myristica (leaf), $P$. oliveri (leaf), and $U$. banmanni (leaf). The MIC values of these fractions ranged from 2.5 to $>10 \mathrm{mg} / \mathrm{ml}$. The most active was the hexanic fraction from the stem of $U$. angolensis (UAst $\mathrm{H}$ ) that exhibited potent fungicidal effects against $C$. albicans and $C r$. neoformans ( $\mathrm{MIC}=2.5$ $\mathrm{mg} / \mathrm{mL} ; \mathrm{MFC}=5 \mathrm{mg} / \mathrm{mL}$ ), and to a certain extent against $C$. parapsilosis $(\mathrm{MIC}=2.5$ $\mathrm{mg} / \mathrm{mL} ; \mathrm{MFC}>10 \mathrm{mg} / \mathrm{mL}$ ). In this particular case, the partition of the mother crude extract has delivered a two-fold more potent hexanic fraction and an aqueous fraction with mother extract-like activity (MIC of $5 \mathrm{mg} / \mathrm{mL}$; MFC $>10 \mathrm{mg} / \mathrm{mL}$ against $C$. parapsilosis and $C r$. neoformans, and MIC of $10 \mathrm{mg} / \mathrm{mL}$; MFC > $10 \mathrm{mg} / \mathrm{mL}$ against $C$. albicans). Besides, it was noticed that fractionation did not show any overall activity improvement from the other partitioned extracts. Consequently, fraction UAst $\mathrm{H}$ from the stem of $U$. angolensis was selected for further phytochemical screening and combination studies.

\section{Phytochemical \\ screening \\ of fraction UAst $H$}

Qualitative phytochemical screening using standards methods has revealed the presence of a number of secondary metabolite classes in fraction UAst $\mathrm{H}$ that might sustain the observed activity against yeasts. These metabolites included phenols, flavonoids, triterpenes, steroids, saponins, anthocyanins, tannins, and essentials oils.

\section{Fraction UAst $H$ and ketoconazole combination studies}

Fraction UAst $\mathrm{H}$ and ketoconazole were combined at their respective MIC values using the checkerboard format and tested against C. albicans, C. parapsilosis, and $\mathrm{Cr}$. neoformans. Fractional inhibitory concentration indexes (FICI) were calculated and the type of interaction between the two reactants determined. The results obtained are summarized in the Table 4 below.

From the results presented in Table 4, the FICI values were found to range from 0.26 to 0.75 against $C$. albicans, from 0.28 to 0.75 against $C r$. neoformans, and from 0.15 to 0.51 against $C$. parapsilosis. Overall, synergistic interactions could be achieved with most of the combinations, resulting in average FICI of $0.47 \pm 0.19,0.38 \pm 0.21$ and $0.29 \pm 0.15$ on C. albicans, Cr. neoformans, and C. parapsilosis and significant reduction in MIC values of both UAst $\mathrm{H}$ fraction and ketoconazole. Besides, only three additive interactions were observed against $C$. albicans, and one each against $C$. parapsilosis and $\mathrm{Cr}$. neoformans. Moreover, the reduction of ketoconazole's MIC ranged from 2 to 32-fold, and from 2 to 64 fold for UAst $\mathrm{H}$. 
Table 2: Extraction yield and results of anti-yeast screening of ethanolic extracts.

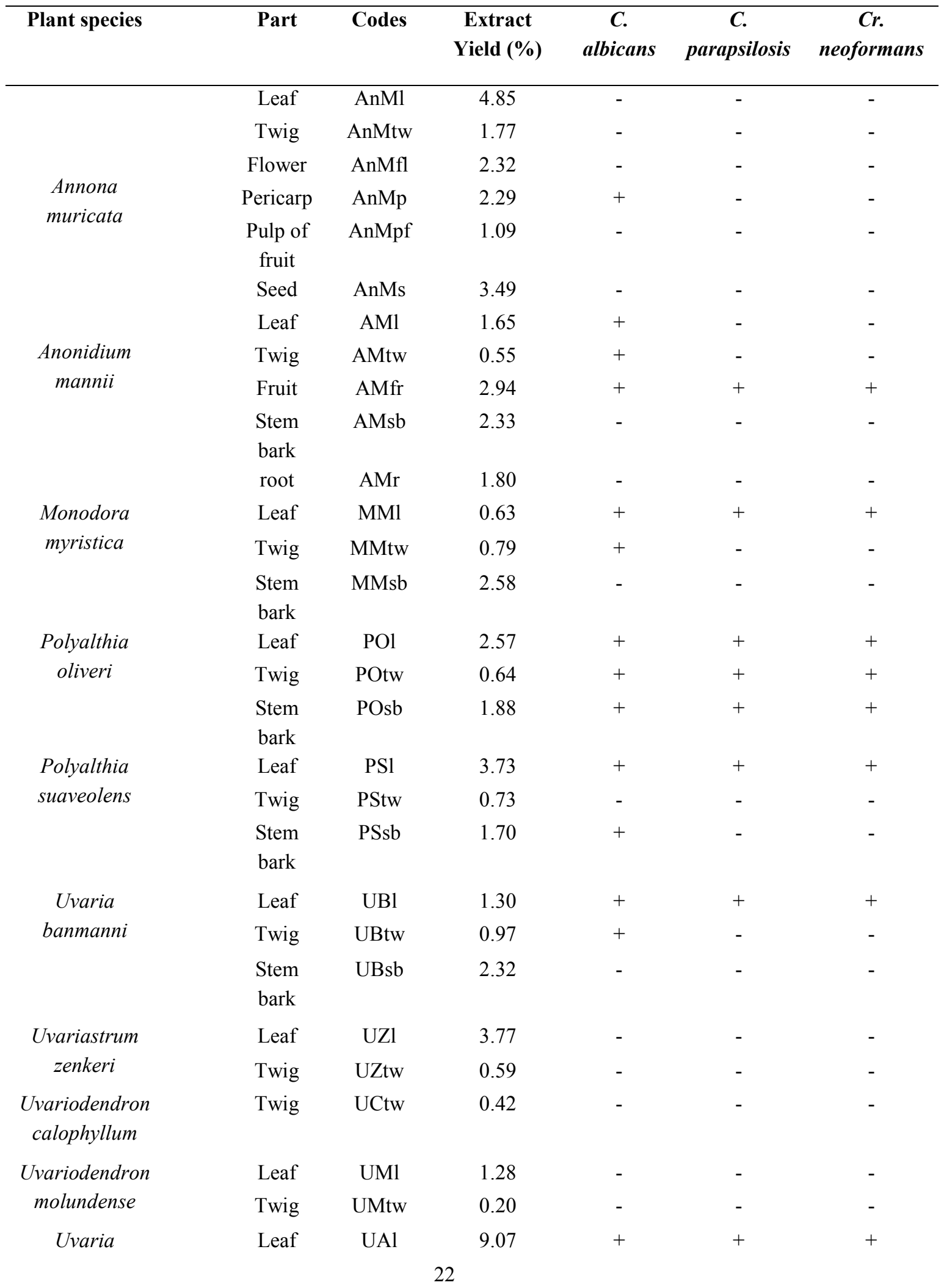


TAFFOU et al. / Int. J. Biol. Chem. Sci. 11(1): 15-31, 2017

\begin{tabular}{ccccccc} 
angolensis & Twig & UAtw & 8.83 & + & + & + \\
Uvaria & Stem & UAst & 13.94 & + & + & + \\
muricata & Leaf & UMul & 12.97 & - & - & - \\
& Twig & UMutw & 5.30 & + & + & + \\
Xylopia & Stem & UMust & 4.84 & + & + & + \\
africana & Leaf & XAl & 3.99 & - & - & - \\
& Twig & XAtw & 0.75 & + & - & - \\
& Stem & XAsb & 1.57 & + & - & - \\
& bark & & & & & - \\
Xylopia & root & XAr & 0.49 & + & - & - \\
aethiopica & Leaf & XAEl & 4.27 & + & - & - \\
& Stem & XAEst & 0.10 & - & - & - \\
Xylopia & seed & XAEs & 1.98 & - & - & - \\
parviflora & Leaf & XPl & 1.65 & + & - & + \\
Ketoconazole & Stem & XPst & 0.67 & - & - & + \\
\hline
\end{tabular}

-: no inhibition at $10 \mathrm{mg} / \mathrm{mL} ;+: 100 \%$ inhibition at $10 \mathrm{mg} / \mathrm{mL}$

Table 3: MIC and MFC of extracts and fractions ( $\mathrm{mg} / \mathrm{mL})$.

\begin{tabular}{|c|c|c|c|c|c|c|c|c|}
\hline \multirow[t]{2}{*}{ Plant species } & \multirow[t]{2}{*}{ Part } & \multirow[t]{2}{*}{ Extract/fraction } & \multicolumn{2}{|c|}{ C. albican } & \multicolumn{2}{|c|}{ C. parapsilosis } & \multicolumn{2}{|c|}{ Cr. neoformans } \\
\hline & & & MIC & MFC & MIC & MFC & MIC & MFC \\
\hline \multirow{3}{*}{$\begin{array}{c}\text { Anonidium } \\
\text { mannii }\end{array}$} & Fruit & AMfr & 10 & $>10$ & 10 & 10 & 10 & 10 \\
\hline & & AMfr H & $>10$ & $>10$ & $>10$ & $>10$ & $>10$ & $>10$ \\
\hline & & $\mathrm{AMfr} \mathrm{H}_{2} \mathrm{O}$ & $>10$ & $>10$ & $>10$ & $>10$ & $>10$ & $>10$ \\
\hline \multirow{4}{*}{$\begin{array}{c}\text { Monodora } \\
\text { myristica }\end{array}$} & Leaf & MMl & 5 & $>10$ & 5 & $>10$ & 5 & $>10$ \\
\hline & & MMl I & $>10$ & $>10$ & $>10$ & $>10$ & $>10$ & $>10$ \\
\hline & & MMl H & $>10$ & $>10$ & $>10$ & $>10$ & $>10$ & $>10$ \\
\hline & & $\mathrm{MMl} \mathrm{H}_{2} \mathrm{O}$ & $>10$ & $>10$ & $>10$ & $>10$ & $>10$ & $>10$ \\
\hline \multirow{6}{*}{$\begin{array}{c}\text { Polyalthia } \\
\text { oliveri }\end{array}$} & Leaf & $\mathrm{POl}$ & 10 & $>10$ & 10 & $>10$ & 2.5 & 5 \\
\hline & & PO1 I & $>10$ & $>10$ & $>10$ & $>10$ & $>10$ & $>10$ \\
\hline & & $\mathrm{POl} \mathrm{H}$ & 10 & $>10$ & $>10$ & $>10$ & 5 & 5 \\
\hline & & $\mathrm{POl} \mathrm{H}_{2} \mathrm{O}$ & $>10$ & $>10$ & $>10$ & $>10$ & $>10$ & $>10$ \\
\hline & Twig & POtw & 10 & $>10$ & 10 & $>10$ & $>10$ & $>10$ \\
\hline & & POtw $\mathrm{H}$ & $>10$ & $>10$ & $>10$ & $>10$ & $>10$ & $>10$ \\
\hline
\end{tabular}


TAFFOU et al. / Int. J. Biol. Chem. Sci. 11(1): 15-31, 2017

\begin{tabular}{|c|c|c|c|c|c|c|c|c|}
\hline & & POtw $\mathrm{H}_{2} \mathrm{O}$ & $>10$ & $>10$ & $>10$ & $>10$ & $>10$ & $>10$ \\
\hline & Stem & POsb & 10 & $>10$ & 10 & $>10$ & 10 & $>10$ \\
\hline & bark & POsb $\mathrm{H}$ & $>10$ & $>10$ & $>10$ & $>10$ & $>10$ & $>10$ \\
\hline & & POsb $\mathrm{H}_{2} 0$ & $>10$ & $>10$ & $>10$ & $>10$ & $>10$ & $>10$ \\
\hline \multirow{3}{*}{$\begin{array}{l}\text { Polyalthia } \\
\text { suaveolens }\end{array}$} & Leaf & PSl & 10 & 10 & 10 & $>10$ & 10 & $>10$ \\
\hline & & PS1 H & $>10$ & $>10$ & $>10$ & $>10$ & $>10$ & $>10$ \\
\hline & & PSl $\mathrm{H}_{2} 0$ & $>10$ & $>10$ & $>10$ & $>10$ & $>10$ & $>10$ \\
\hline \multirow{4}{*}{$\begin{array}{c}\text { Uvaria } \\
\text { banmanni }\end{array}$} & Leaf & UBl & 0.625 & 1.25 & 10 & $>10$ & 10 & $>10$ \\
\hline & & UBl I & $>10$ & $>10$ & $>10$ & $>10$ & $>10$ & $>10$ \\
\hline & & UB1 H & $>10$ & $>10$ & $>10$ & $>10$ & $>10$ & $>10$ \\
\hline & & $\mathrm{UB} 1 \mathrm{H}_{2} \mathrm{O}$ & $>10$ & $>10$ & $>10$ & $>10$ & $>10$ & $>10$ \\
\hline \multirow{9}{*}{$\begin{array}{c}\text { Uvaria } \\
\text { angolensis }\end{array}$} & Leaf & UAl & 10 & $>10$ & 5 & $>10$ & 10 & $>10$ \\
\hline & & UAl H & 10 & $>10$ & 10 & $>10$ & 10 & $>10$ \\
\hline & & $\mathrm{UAl} \mathrm{H}_{2} 0$ & 10 & $>10$ & 10 & $>10$ & 5 & $>10$ \\
\hline & twig & UAtw & 5 & $>10$ & 5 & $>10$ & 5 & $>10$ \\
\hline & & UAtw H & $>10$ & $>10$ & $>10$ & $>10$ & $>10$ & $>10$ \\
\hline & & UAtw $\mathrm{H}_{2} 0$ & 5 & $>10$ & 5 & $>10$ & 5 & $>10$ \\
\hline & stem & UAst & 10 & $>10$ & 5 & $>10$ & 5 & $>10$ \\
\hline & & UAst $\mathrm{H}$ & 2.5 & 5 & 2.5 & $>10$ & 2.5 & 5 \\
\hline & & UAst $\mathrm{H}_{2} 0$ & 10 & $>10$ & 5 & $>10$ & 5 & $>10$ \\
\hline \multirow{6}{*}{$\begin{array}{c}\text { Uvaria } \\
\text { muricata }\end{array}$} & twig & UMutw & 5 & $>10$ & 10 & $>10$ & 5 & $>10$ \\
\hline & & UMutw H & 5 & $>10$ & 5 & $>10$ & 10 & $>10$ \\
\hline & & UMutw $\mathrm{H}_{2} 0$ & 5 & $>10$ & 5 & $>10$ & 5 & $>10$ \\
\hline & stem & UMust & 10 & $>10$ & 5 & $>10$ & 5 & $>10$ \\
\hline & & UMust H & 10 & $>10$ & 5 & $>10$ & 2.5 & $>10$ \\
\hline & & UMust $\mathrm{H}_{2} 0$ & 5 & $>10$ & 5 & $>10$ & 5 & $>10$ \\
\hline \multirow{3}{*}{$\begin{array}{c}\text { Xylopia } \\
\text { parviflora }\end{array}$} & Seed & XPs & 10 & 10 & 10 & $>10$ & 10 & $>10$ \\
\hline & & XPs H & $>10$ & $>10$ & $>10$ & $>10$ & $>10$ & $>10$ \\
\hline & & XPs $\mathrm{H}_{2} \mathrm{O}$ & $>10$ & $>10$ & $>10$ & $>10$ & $>10$ & $>10$ \\
\hline Ketoconazole & & & 10 & 10 & 5 & 10 & 5 & 10 \\
\hline
\end{tabular}


TAFFOU et al. / Int. J. Biol. Chem. Sci. 11(1): 15-31, 2017

Table 4: Effect of combined UAst H fraction and ketoconazole on C. albicans, C. parapsilosis and Cr. Neoformans.

\begin{tabular}{|c|c|c|c|c|c|c|c|c|c|c|c|}
\hline \multicolumn{2}{|c|}{ C. albicans } & \multirow{2}{*}{$\begin{array}{c}\text { FICI (FIC Keto } \\
+ \text { FIC UAst H) }\end{array}$} & \multirow[t]{2}{*}{ Int } & \multicolumn{2}{|c|}{ Cr. neoformans } & \multirow{2}{*}{$\begin{array}{c}\text { FICI } \\
\text { (FIC Keto } \\
+ \text { FIC UAst H) }\end{array}$} & \multirow[t]{2}{*}{ Int } & \multicolumn{2}{|c|}{ C. parapsilosis } & \multirow{2}{*}{$\begin{array}{c}\text { FICI } \\
\text { (FIC Keto } \\
+ \text { FIC UAst H) }\end{array}$} & \multirow[t]{2}{*}{ In } \\
\hline FIC & FIC & & & FIC & FIC Keto & & & FIC & FIC Keto & & \\
\hline UAst H & Keto & & & UAst $\mathrm{H}$ & & & & UAst H & & & \\
\hline 0.25 & 0.01 & 0.26 & $\mathrm{~S}$ & 0.25 & 0.03 & 0.28 & $\mathrm{~S}$ & 0.13 & 0.03 & 0.15 & $\mathrm{~S}$ \\
\hline 0.50 & 0.03 & 0.53 & $\mathrm{~A}$ & 0.25 & 0.06 & 0.31 & $\mathrm{~S}$ & 0.13 & 0.06 & 0.18 & $\mathrm{~S}$ \\
\hline 0.50 & 0.06 & 0.56 & $\mathrm{~A}$ & 0.13 & 0.06 & 0.18 & $\mathrm{~S}$ & 0.13 & 0.13 & 0.25 & $\mathrm{~S}$ \\
\hline 0.13 & 0.13 & 0.25 & $\mathrm{~S}$ & 0.13 & 0.25 & 0.37 & $\mathrm{~S}$ & 0.13 & 0.25 & 0.37 & $\mathrm{~S}$ \\
\hline 0.25 & 0.25 & 0.50 & $\mathrm{~S}$ & 0.25 & 0.50 & 0.75 & $\mathrm{~A}$ & 0.01 & 0.50 & 0.51 & A \\
\hline 0.25 & 0.50 & 0.75 & $\mathrm{~A}$ & & & & & & & & \\
\hline \multicolumn{2}{|c|}{ Average of } & $0.47 \pm 0.19$ & $\mathrm{~S}$ & \multicolumn{2}{|c|}{ Average of } & $0.38 \pm 0.21$ & $\mathrm{~S}$ & \multicolumn{2}{|c|}{ Average of } & $0.29 \pm 0.15$ & $\mathrm{~S}$ \\
\hline \multicolumn{2}{|c|}{ FIC Index } & & & \multicolumn{2}{|c|}{ FIC Index } & & & \multicolumn{2}{|c|}{ FIC Index } & & \\
\hline
\end{tabular}




\section{DISCUSSION}

Plants species from Annonaceae family are worldwide distributed and used all over the tropics in traditional medicine for the treatment of parasitic and microbial diseases, including fungal and bacterial infections. As reported by Tsabang et al (2012), Annonaceae plants are widely used by Cameroonian traditional healers to cure malaria and related symptoms, and many other infections. Moreover, phytochemical studies of this family have revealed chemical components which could offer new alternatives for the treatment and control of several infectious diseases (Frausin et al., 2014). Of note, secondary metabolites with antimicrobial activity from classes of alkaloids, flavonoids, tannins, phenolic compounds, anthocyanins, saponins, triterpenes, steroids, and acetogenins have been reported from many Annonaceae plant species (Leboeuf et al., 1980; Lewis and Ausubel, 2006; Taha et al 2013; Frausin et al., 2014; Liaw et al., 2016).

From the present investigation, fourteen different plants species from eight genera were investigated for their potential to inhibit the growth of Candida albicans, Candida parapsilosis and Cryptococcus neoformans. The results showed that few extracts and fractions could inhibit the tested yeasts. Of particular interest, the hexane fraction (UAst $\mathrm{H}$ ) obtained from the water/hexane partition of the stem extract of Uvaria angolensis exhibited potent inhibitory effects against the three pathogens, more likely due to its content in secondary metabolites that have been shown to possess antifungal activity. This active fraction has also exhibited remarkable synergistic activity in combination with Ketoconazole (FICI from $0.29-0.47$ ) against the three pathogens.

The qualitative phytochemical screening of fraction UAst $\mathrm{H}$ has revealed the presence of phenols, flavonoids, triterpenes, steroids, saponins, anthocyanins, tannins, and essentials oils. These compounds have the potential to exhibit potent activity against yeasts alone or in combination. For instance, phenolic compounds isolated from natural sources possess antifungal properties of interest. Particularly, phenolic acids have shown promising in vitro and in vivo activity against Candida species. However, studies on their mechanism of action alone or in synergism with known antifungals are still scarce (Teodoro et al., 2015). Also, flavonoids used in combination with fluconazole recently showed significant synergistic activity in vitro against Candida tropicalis strains resistant to fluconazole (Da Silva et al., 2014). Similarly, condensed tannins from Stryphnodendron adstringens showed in vitro and in vivo effect on Candida tropicalis growth and adhesion properties (Morey et al., 2016). Steroidal saponins have also been shown to exert significant activity against $\mathrm{Cr}$. neoformans and Aspergillus fumigatus (Yang et al., 2006). Limited studies have indicated that phenols, saponins and flavonoids might exert their antimicrobial action through membrane perturbations (Tsuchiya et al 1996; Majorie, 1999; Cushnie and Lamb, 2005). As well, essential oils that are complex volatile compounds, synthesized naturally in different plant parts during the process of secondary metabolism have great potential in the field of biomedicine as they effectively destroy several bacterial, fungal, and viral pathogens. The presence of different types of aldehydes, phenolics, terpenes, and other antimicrobial compounds means that the essential oils are effective against a diverse range of pathogens.

A tentative explanation of the observed synergistic action of fraction UAst $\mathrm{H}$ in combination with ketoconazole might be the disruption of cell membrane coupled with the impairing effect of ketoconazole on the synthesis of membrane ergosterol (Ghannoum and Rice, 1999). Furthermore, these results are consistent with previous studies where 
plant extracts were reported to increase in vitro efficacy of available antimicrobial drugs against bacteria and fungi (Betoni et al., 2006; Esimone et al., 2006; Horiuchi et al., 2007).

Opportunistic fungal infections elicited by Candida, Cryptococcus, and Aspergillus are life-threatening in immunocompromised patients (with AIDS, cancer, or organ transplant) (Liu and Lian, 2003). The currently prescribed antifungal drugs belong to five major drug classes, namely 1) polyenes (ex. Amphotericin B; interacting with fungal ergosterol, thereby disrupting the cytoplasmic membrane); 2) azoles (ex. Ketoconazole, fluconazole; inhibiting $14 \alpha$-lanosterol demethylase in ergosterol biosynthesis pathway); 3) allylamines (ex. terbinafine, butenafine; inhibiting squalene epoxidase in ergosterol synthesis pathway), 4) echinocandins (ex. caspofungin, anidulafungin; inhibiting synthesis of $\beta-1,3-$ glucan, which is a required component of the cell wall of many fungi), and 5) flucytosine (ex. flucytosine; incorporated into RNA and thus inhibiting DNA synthesis) (Ren, 2004). Unfortunately, each of these drug classes have at least one major shortcomings such as significant dose-limiting toxicities for Amphotericin B, rapid development of resistance for the azoles, limitation of the use to dermatophytoses for terbinafine, and lack of effectiveness in cryptococcosis for caspofungin) (Marr et al., 2001, 1998; Liang and Wang, 2004). This has emphasized the need to discover new antifungal agents, preferably with new modes of action. In fact, plant extracts can be used as synergistic enhancers even if they don't have any antimicrobial properties alone. They can enhance the effect of standard drugs when they are taken concurrently (Horiuchi et al., 2007). Many attempt to formulate such combinations either with commercially available antifungals, or potent phytochemicals have been described (Sibanda and Okoh, 2007; Adwan and Mhanna, 2008). In addition to the results described in this study, recent findings also support that plant extracts from Annonaceae have the potential to be further developed as drugs to control fungal diseases. For instance, methanol, chloroform, and aqueous extracts of Annona squamosa leaves recently showed activity against five different strains of fungi (Alternaria alternata, Candida albicans, Fusarium solani, Microsporum canis, and Aspergillus niger) (Kalidindi et al., 2015). Also, antifungal activity of ethanolic, methanolic, and aqueous extracts of Annona muricata was recently reported against $C$. albicans and Cr. neoformans (Vinothini and Growther, 2016). These previous findings further emphasize the potential of Annonaceae extracts as sources of potent antifungal agents.

\section{Conclusion}

The results from this investigation suggest that plants species from Annonaceae family can be used as promising sources for antifungal drug discovery. Moreover, the synergistic interaction of fraction UAst $\mathrm{H}$ from Uvavia angolensis with ketoconazole against the tested yeasts further suggest the possibility of development of novel synergistic antiyeast therapies from such extracts. However, in an optic to develop new drugs against opportunistic mycosis, further detailed studies of the selected fraction are required.

\section{COMPETING INTERESTS}

The authors declare that they have no competing interests.

\section{AUTHORS' CONTRIBUTIONS}

This work was designed and supervised by FFB. Taffou, JBHF, EZM, LRYT, ANF, MSK, VN, IFKT collected and extracted the plants materials. They also performed the in vitro screening of plant 
extracts. All authors contributed to manuscript drafting and revision.

\section{ACKNOWLEDGMENTS}

The authors are very grateful for the practical assistance of Mr. Victor Nana of the National Herbarium of Cameroon in identifying and archiving voucher specimens of the investigated plants.

\section{REFERENCES}

Adwan G, Mhanna M. 2008. Synergistic effects of plant extracts and antibiotics on Staphylococcus aureus strains isolated from clinical specimens. MiddleEast J. Sci. Res., 3: 134-139.

Bakarnga-Via I, Fokou JBH, Fokou PVT, Tchokouaha LRY, Gary-Bobo M, Gallud A, Garcia M, Secka Y, Dongmo PMJ, Boyom FF, Menut C, Walbadet L. 2014. Composition and cytotoxic activity of essential oils from Xylopia aethiopica (Dunal) A. Rich, Xylopia parviflora (A. Rich) Benth.) and Monodora myristica (Gaertn) growing in Chad and Cameroon. BMC Compl. Alter. Med., 14: 125. DOI: $10.1186 / 1472-6882-14-125$

Betoni JEC, Mantovani RP, Barbosa LN, Stasi LCD, Junior AF. 2006. Synergism between plant extract and antimicrobial drugs used on Staphylococcus aureus diseases. Mem. Inst. Osw. Cruz, 101: 387-390.

Boyom FF, Kemgne EM, Tepongning R, Ngouana V, Mbacham WF, Tsamo E, Amvam ZPH, Gut J, Rosenthal PJ. 2009. Antiplasmodial activity of extracts from seven medicinal plants used in malaria treatment in Cameroon. $J$. Ethnopharmacol., 123: 483-488. DOI: 10.1016/j.jep.2009.03.008.

Boyom FF. 2004. Essential Oils of Cameroonian Annonaceae: Chemical Analysis, Antioxydant and
Antiplasmodial Activities, Doctorat d'Etat thesis, University of Yaoundé I.

Clinical and Laboratory Standard Institute (CLSI). 2008. Reference Method for Broth Dilution Antifungal Susceptibility Testing of Yeasts, Approved standard, third edition M27- A3: Wayne, PA, USA.

Corbett EL, Churchyard GJ, Charalambos S, Samb B, Moloi V, Clayton TC, Grant AD, Murray J, Hayes RJ, De Cock KM. 2002. Morbidity and mortality in South Africa gold miners: impact of untreated disease due to human immunodeficiency virus. Clin. Infect. Dis., 34: 1251-1258.

Cushnie TPT, Lamb AJ. 2005. Antimicrobial activity of flavonoids. Int. J. Antimicrob. Agents, 26: 343-356.

Da Silva CR, De Andrade Neto JB, De Sousa Campos R, Figueiredo NS, Sampaio LS, Magalhães HIF, Cavalcanti BC, Gaspar DM, De Andrade GM, Lima ISP, De Barros Viana GS, De Moraes MO, Lobod MDP, Grangeiro TB, Nobre Júnior HV. 2014. Synergistic Effect of the Flavonoid Catechin, Quercetin, or Epigallocatechin Gallate with Fluconazole Induces Apoptosis in Candida tropicalis Resistant to Fluconazole. Antimicrob. Agents Chemother., 58(3): 1468-1478.

Dias DA, Urban S, Roessner U. 2012. A Historical Overview of Natural Products in Drug Discovery. Metabolites, 2(2):303-336. doi:10.3390/metabo2020303.

Donfack DVF, Roque S, Trigo G, Fokou PVT, Tchokouaha LRY, Tsabang N, Zollo PHA, Correia-Neves M, Boyom FF. 2014. Antimycobacterial activity of selected medicinal plants extracts from Cameroon. Int. J. Biol. Chem. Sci., 8(1): 273-288.

Esimone CO, Iroha IR, Ibezim EC, Okeh CO, Okpana EM. 2006. In vitro evaluation of 
the interaction between tea extracts and penicillin G against Staphylococcus aureus. Afr. J. Biotechnol., 5: 10821086.

Fokou JBH, Jazet DPM, Bakarnga-Via I, Ngo mback MNL, Menkem EZ, Fall AD, Bassene E, Boyom FF. 2014. Optimized combinations of Ocimum essential oils inhibit growth of four Candida albicans. Int. J. Drug Discov., 6(6): 198-206.

Frausin, Gina, Lima, Renata Braga Souza, Hidalgo, Ari de Freitas, Maas, Paul, \& Pohlit, Adrian Martin. (2014). Plants of the Annonaceae traditionally used as antimalarials: a review. Revista Bras. Fruticult., 36(1): 315-337.

Ghannoum MA, Rice LB. 1999. Antifungal agents: mode of action, mechanisms of resistance and correlation of these mechanisms with bacterial resistance. Clin. Microbiol. Rev., 12: 501-517.

Hachem R, Hanna H, Kontoyiannis D, Jiang Y, Raad I. 2008. The changing epidemiology of invasive candidiasis: Candida glabrata and Candida krusei as the leading causes of candidemia in hematologic malignancy. Cancer, 112: 2493-2499.

Horiuchi K, Shiota S, Kuroda T, Hatano T, Yoshida T, Tsuchiya T. 2007. Potentiation of antimicrobial activity of aminoglycosides by carnosol from Salvia officinalis. Biol. Pharm. Bull., 30: 287290.

Horn DL, Neofytos D, Anaissie EJ, Fishman JA, Steinbach WJ, Olyaei AJ, Marr KA, Pfaller MA, Chang $\mathrm{CH}$, Webster KM. 2009. Epidemiology and outcomes of candidemia in 2019 patients: data from the prospective antifungal therapy alliance registry. Clin. Infect. Dis., 48: 1695-1703.

Hufford CD, Babajide OO, James SN. 1987. Angoluvarin, an antimicrobial dihydrochalcone from Uvaria angolensis. J. Org. Chem., 52: 52865288.

Kalidindi N, Thimmaiah NV, Jagadeesh NV, Nandeep R, Swetha S, Kalidindi B. 2015. Antifungal and antioxidant activities of organic and aqueous extracts of Annona squamosa Linn. Leaves. $J$. Food \& Drug Analys., 23(4): 795-802.

Kamdem MS, Sameza ML, Dongmo PMJ, Boyom FF, Bakargna-Via I, Fokou JBH, Tsague IFK, Menkem EZ, Zollo PHA, Menut C. 2015. Antiradical, Antiinflammatory and Antifungal Activities of Essential Oils of Two Aromatic Plants: Apium graveolens (Apiaceae) and Thymus vulgaris (Lamiaceae). J. Life Sci., 9: 51-64.

Kammalac TN, Mbouna CDJ, Kuipou RMT, Tchuenmogne MAT, Menkem EZ, Ngouana V, Mallié M, Bertout S, Boyom FF. 2015. Potent and Synergistic Extract Combinations from Terminalia catappa, Terminalia mantaly and Monodora tenuifolia Against Pathogenic Yeasts. Medicines, 2: 220-235.

Khan PA, Malik A, Khan HS. 2012. Profile of candidiasis in HIV infected patients. Iran. J. Microbiol., 4: 204-209.

Leboeuf M, Cavé A, Bhaumik PK, Mukherjee B, Mukherjee R. 1980. The phytochemistry of the Annonaceae. Phytochem., 21(12): 2783-2813.

Lewis K, Ausubel FM. 2006. Prospects for plant derived antibacterials. Nat. Biotechnol., 24:1504-1507.

Liang BB, Wang R. 2004. The adverse reaction and advances in study on antifungal drugs. Clin. Med. J. 2: 5-12.

Liaw CC, Liou JR, Wu TY, Chang FR, Wu YC. 2016. Acetogenins from Annonaceae. Progr. Chem. Org. Nat. Prod., 101: 113-228.

Liu WD, Lian CH. 2003. The early stage diagnosis of deep-seated fungal 
infections. Chin. J. Lab. Med., 26: 583584.

Majorie MC. 1999. Plant products as antimicrobial agents. Clin. Microbiol. Rev., 12(4): 564-582.

Marr KA, Lyons CN, Ha K, Rustad T, White TC. 2001. Inducible azole resistance associated with a heterogeneous phenotype in Candida albicans. Antimicrob. Agents Chemother., 45: 5259.

Marr KA, Lyons CN, Rustad T, Bowden RA, White TC. 1998. Rapid, transient fluconzole resistance in Candida albicans is associated with increased mRNA levels of CDR. Antimicrob. Agents Chemother., 42: 2584-2589.

Menkem EZ, Lopez VC, Soto SM, Boyom FF. 2016. Anti-candida biofilm properties of Cameroonian plant extracts. J. Med. Plants Res., 10(35): 603-611.

Menkem EZ, Kouipou RMT, Mbouna CDJ, Djouonzo PT, Kammalac TN, Fokou PVT, Boyom FF. 2015. Anti-yeast activity of extracts and fractions from Uvariodendron calophyllum (Annonaceae). Int. J. Biol. Chem. Sci., 9(6): 2500-2522.

Mirza SA, Phelan M, Rimland D, Graviss E, Hamill R, Brandt ME, Gardner T, Sattah M, de Leon GP, Baughman W, Hajjeh RA. 2003. The changing epidemiology of cryptococcosis: an update from population-based active surveillance in 2 large metropolitan areas, 1992-2000. Clin. Infect. Dis., 36: 789-794.

Morey AT, de Souza FC, Santos JP, Pereira CA, Cardoso JD, de Almeida RS, Costa MA, de Mello JC, Nakamura CV, PingeFilho P, Yamauchi LM, Yamada-Ogatta SF. 2016. Antifungal Activity of Condensed Tannins from Stryphnodendron adstringens: Effect on Candida tropicalis Growth and
Adhesion Properties. Curr. Pharm. Biotechnol., 17(4): 365-375.

Nucci M, Marr KA. 2005. Emerging fungal diseases. Clin. Infect. Dis., 41: 521-526.

Odebeyi OO, Sofowora EA. 1978. Phytochemical screening: Nigeria medical plants. L. Coydia, 41: 234-325.

Okonkwo E, Alo MN, Nworie O, Orji JO, Agah MV. 2013. Prevalence of oral Candida albicans infection in HIV seropositive patients in Abakaliki. Am. J. Life Sci., 1: 72-76. Doi: 10.11648/j.ajls.20130102.18.

Perfect JR, Dismukes WE, Dromer F, Goldman DL, Graybill JR, Hamill RJ, Harrison TS, Larsen RA, Lortholary O, Nguyen MH, Pappas PG, Powderly WG, Singh N, Sobel JD, Sorrell TC. 2010. Clinical practice guidelines for the management of cryptococcal disease: 2010 update by the Infectious Diseases Society of America. Clin. Infect. Dis., 50(3): 291-322.

Pinto AC, Andrade SR, Ferreira FR, Kinpara DI. 2005. Annona species. In International Center for under Utilised Crops; University of Southampton: Southampton, UK, pp. 1-281.

Ren LJ. 2004. The clinical application of common antifungal drugs. China New Med., 3: 63-64.

Romeo O, Tietz H-J, Criseo G. Candida Africana. 2013. Is it a fungal pathogen? Curr. Fungal Inf. Rep., 1: 1-6.

Ruhnke M. 2006. Epidemiology of Candida albicans infections and role of nonCandida albicans yeasts. Curr. Drug Targets, 7: 495-504.

Sibanda T, Okoh A. 2007. The challenges of overcoming antibiotic resistance: Plant extracts as potential sources of antimicrobial and resistance modifying agents. Afr. J. Biotechnol., 6: 2886-2896.

Sidjui SL, Menkem EZ, Kouipou RMT, Noté PO, Mahiou-Leddet V, Gaëtan $\mathrm{H}$, 
Boyom FF, Ollivier E, Folefoc NG. 2014. Secondary Metabolites from Jacaranda mimosifolia and Kigelia africana (Bignoniaceae) and their Anticandidal activity. Rec. Nat. Prod., 8(3): 307-311.

Taha HA, Hamid A, Hadi Mustafa AM. 2013.

A Brief Review on Bioactive Compounds from Pseuduvaria Species. Open Conf. Proceed. J., 4(2, M2): 3-8.

Tatsadjieu LN, Essia Ngang JJ, Ngassoum MB, Etoa F-X. 2003. Antibacterial and antifungal activity of Xylopia aethiopica, Monodora myristica, Zanthoxylum xanthoxyloudes and Zanthoxylum leprieurii from Cameroon. Fitoterapia, 74: 469-472.

Tchokouaha LRY, Fokou PVT, Mbouna CDJ, Keumoe R, Ndjakou BL, Djouonzo PT, Mfopa AN, Legac J, Tsabang N, Gut J, Rosenthal PJ, Boyom FF. 2015. Extracts from Annona muricata L. and Annona reticulata L. (Annonaceae) potently and selectively inhibit Plasmodium falciparum. Medicines, 2: 55-66.

Teodoro GR, Ellepola K, Seneviratne CJ, Koga-Ito CY. 2015. Potential Use of Phenolic Acids as Anti-Candida Agents: A Review. Front. Microbiol., 6: 1420. Doi:10.3389/fmicb.2015.01420.

Tobudic S, Kratzer C, Anrea Lassnigg A, Graninger W, Prester E. 2010. In vitro activity of antifungal combinations against Candida albicans biofilms. $J$. Antimicrob. Chemother., 65: 271 -274.

Tsabang N, Tsouh FPV, Tchokouaha LRY, Noguem B, Bakarnga-Via I, Dongmo NMS, Nkongmeneck BA, Boyom FF. 2012. Ethnopharmacological survey of Annonaceae medicinal plants used to treat malaria in four areas of Cameroon. J. Ethnopharmacol., 139: 171-180.

Tsuchiya H, Sato M, Miyazaki T, Fujiwara S, Tanigaki S, Ohyama M, Tanaka T, Iinuma M. 1996. Comparative study on the antibacterial activity of phytochemical flavanones against methicillin-resistant Staphylococcus aureus. J. Ethnopharmacol., 50: 27-34.

Vinothini R, Growther, L. 2016. Antimicrobial and Phytochemical Analysis of Methanolic and Aqueous Extract of Annona muricata (Leaf and Fruit). Int. J. Curr. Microbiol. App. Sci., 5(10): 617-625.

Yang C-R, Zhang Y, Jacob MR, Khan SI, Zhang Y-J, Li X-C. 2006. Antifungal Activity of C-27 Steroidal Saponins. Antimicrob. Agents Chemother, 50(5): 1710-1714. 